\title{
Economics
}

The Open-Access, Open-Assessment E-Journal

Vol. 12, 2018-61 | October 12, 2018 | http://dx.doi.org/10.5018/economics-ejournal.ja.2018-61

\section{Tackling energy, climate and development challenges in Africa}

\author{
Shingirirai S. Mutanga, Rainer Quitzow, and Jan Christoph Steckel
}

\begin{abstract}
In order to fulfill multiple sustainable development targets, most prominently human development, poverty eradication and climate change mitigation, African countries need infrastructure that cover basic needs while at the same time promote industrialization and value creation. G20 countries can support African countries by: (1) aligning and cementing the G20 Agenda for Africa with African initiatives, SDGs and the Paris Agreement, (2) mitigating economic risks of climate change through supporting low carbon development pathways in Africa, (3) incentivizing low carbon development by phasing out subsidies and eventually putting a price on carbon and (4) creating and enabling a level playing field for low carbon technologies, which includes integrated strategies for de-risking renewable energy investments.

(Published as Global Solutions Paper)
\end{abstract}

JEL Q01 Q54 H23 R11

Keywords Sustainable development; climate policy; Africa

\section{Authors}

Shingirirai S. Mutanga, Human Science Research Council, South Africa, Pretoria, South Africa; University of Johannesburg, South Africa, smutanga@hsrc.ac.za

Rainer Quitzow, Institute for Advanced Sustainability Studies, Potsdam, Germany;

Technische Universität Berlin, Germany

Jan Christoph Steckel, Mercator Research Institute on Global Commons and Climate

Change, Berlin, Germany; Technische Universität Berlin, Germany; Potsdam Institute for Climate Impact Research, Germany

Citation Shingirirai S. Mutanga, Rainer Quitzow, and Jan Christoph Steckel (2018). Tackling energy, climate and development challenges in Africa. Economics: The OpenAccess, Open-Assessment E-Journal, 12 (2018-61): 1-14.

http://dx.doi.org/10.5018/economics-ejournal.ja.2018-61 


\section{Introduction}

African countries are found to be highly vulnerable to climate change (Niang et al., 2014). This is compounded by the continent's limited capacity for both climate mitigation and adaptation (Doig and Adow, 2011; Shackleton et al., 2015). Combined with the pressures of a rapidly growing and increasingly demanding population, it might be tempting for African countries to pursue a strategy aimed at fueling growth, while relegating environmental concerns for later consideration (Schwerhoff and Sy, 2017). This was the essence of development strategies pursued by both Western industrialized countries and their followers in East Asia and elsewhere (Jakob et al., 2012; Mutanga et al., 2013). If countries on the African continent adopt a similar approach, the achievement of both the Agenda 2030 (the Sustainable Development Goals (SDGs)) as well as the Paris Agreement becomes very unlikely. In particular, SDGs 7 and 13, which focus on sustainable energy and climate action, respectively, would be at risk. At the core of the challenge will be how African countries provide energy in the future, given the multifold interlinkages of energy and other SDGs (McCollum et al., 2018).

In this paper we first discuss the challenges for improving quality of life by investing in sustainable energy. We then develop four proposals how the international community, such as the G20, can support African countries to achieve low carbon development.

\section{Energy challenges for low carbon development in Africa}

In sub-Saharan Africa, about 65 percent of the population (680 million people) lack access to electricity and 81 percent of the population rely on traditional biomass as an energy source (IEA 2016). The use of fuel wood and charcoal contributes to deforestation (e.g. Ahrends et al. 2010), which in turn reduces carbon sequestration by forests, causes soil degradation, decreases climate resilience, and increases disaster risk. Those that have access to electricity, e.g. in cities, often suffer from unreliable access and frequent blackouts, which in turn might impede industrial development (Alicott et al. 2016; Fisher-Vanden et al. 2015, for the cases of India and China, respectively).

Improving access to clean and reliable energy is hence a core policy objective in African countries. It needs to be understood in a broader sense, i.e. beyond covering pure basic needs (UNDP 2010), but also including productive purposes. The reliable provision of electricity and other modern fuels could be a precondition for the improvement of productivity in agriculture, industry or mining sectors. In addition, access to energy influences the use of modern domestic appliances and services, such as cooling or heating. This corresponds to an increased adaptive capacity of the society to climate change impacts (Hassan and Nhemachena 2008). For example, electricity is fundamental to limit the impact of drought in agriculture, and cooling appliances mitigate side effects of heat waves on health. However, increasing access to energy that goes beyond basic needs will generate increasing energy demand, which in the past has often been accompanied by increasing greenhouse gas (GHG) emissions. For example, poor, but fast growing countries in East-, South-, and South-East Asia have traditionally invested in emissions 
intensive coal to cover this demand (Steckel et al. 2015), and recent investment patterns of subSaharan African countries seem to follow this trend (Shearer et al. 2018, Steckel et al. 2018).

In the following, we will discuss the scope of the challenge along three different dimensions: First, we look at energy that is necessary to cover basic needs; second, we look into a broader definition of basic needs, including productive use and societal needs. Finally, we will discuss the role of long term lock-ins into fossil energy dominated energy systems.

\section{$2.1 \quad$ Basic needs}

Despite the non-linear nature of shifts from traditional to modern fuels, incremental levels of access to energy services can enhance economic growth and welfare. The positive effects of basic energy access on welfare include productivity, health, gender equality and education (Alstone et al. 2015 and literature cited therein), even though the effects are not always proven to hold in the African context (Peters and Sievert 2016). Providing universal access to both electricity and clean cooking devices could save 0.4 million premature deaths (in 2030) that might otherwise be attributed to the use of biomass and other solid fuels, such as charcoal (Pachauri et al. 2013). In order to achieve universal access in sub-Saharan Africa, investments of USD 19-40 billion per year until the year 2030 would be required. However, in order to achieve this goal, countries in sub-Saharan Africa would need to undergo unprecedented rates of improvement in energy access, contrary to historical observations in other countries and regions (Rao and Pachauri 2017). It is important to note that providing basic energy access will lead to very limited additional GHG emissions (Pachauri et al. 2013).

\subsection{Productive use and modern societal needs}

A large number of studies have empirically assessed the drivers of energy use and emissions from a global cross-country perspective and find that developing countries' economic convergence to richer countries' income levels and economic structures, is accompanied by convergence of energy use patterns (rather than decoupling) (Csereklyei and Stern 2015, Jakob et al. 2012). Societies that have achieved high levels of human development all show final energy demands of more than 40 GJ per capita per year, which is far from being achieved in most sub-Saharan African countries (Steckel et al. 2013). While there is no doubt that energy consumption in industrialized countries needs to decrease, there is broad agreement that development will not be possible without its increase in most African countries. A range of technological solutions will have to contribute to needs-oriented supply. While off-grid applications such as solar can be an affordable and clean alternative, they will not be able to cover the full range of household and productive energy needs (Lee et al. 2016). They thus need to be complemented by mini- and on-grid solutions. 


\subsection{Creating new lock-ins}

Given that sub-Saharan African countries face massive investment needs in power generation capacity in the near future, covering a large share of this demand with fossil fuels, such as coal, would lead to severe lock-in effects that can endanger ambitious international climate targets or run the risk of being stranded (Pfeiffer et al., 2016). Based on scenarios, it is estimated that in the absence of climate policy, (continental) Africa's emissions will increase 7 to 15 times by 2100, accounting for 3-23\% of global emissions by that time (Lucas et al., 2015; Calvin et al., 2016).

In addition to direct investments to the energy sector, investment needs in physical infrastructure (e.g., roads, buildings, cities) will be tremendous. For example, African countries are experiencing a fast urbanization process. In 2050, 55 percent of the population is expected to live in cities (up from 37 percent in 2014) (UN 2014). The construction of new urban infrastructure and climate resilient human settlements will not only require a large level of energy that is embedded in materials, such as steel and concrete (Steckel et al., 2013), but also implicit in expected appliance use. For example, Levesque et al. (2018) in a scenario framework show that energy demand by appliances and buildings soars particularly in the second half of the 21st century. Due to its longevity and potentially carbon-intensive nature, the extent and form of urban infrastructure will also determine levels of energy use and hence emissions for decades to come. Sustainable urban planning has hence a decisive role in shaping African cities and requires investments in energy saving infrastructures, the provision of basic services and the greening of the energy and transport sectors (Creutzig et al., 2016). African cities also play a particularly important role when it comes to decreasing the demand for charcoal (Ahrends et al., 2010, Bensch and Peters, 2013, Bensch et al., 2015). This in turn affects both human health and deforestation. Additionally, urbanization patterns in Africa are challenging as cities increasingly eat into the most productive lands, which challenges food supply in the future (Bren d'Amour et al., 2016).

\section{Proposals for supporting low carbon development}

Given the particular challenges for low carbon development in Sub-Sahara Africa, when it comes to international support we cluster potential solutions along three basic lines. First, international action and support should be coordinated and aligned with existing agendas, plans and most importantly African initiatives. Second, strategies need to be designed to fulfill the specific demands. For example, meeting the goals of the Paris Agreement would implicitly imply leapfrogging fossil-fuel development pathways for most African countries, which is unprecedented in history. Third, the specific market and investment environments in African countries need to be taken into account. This aspect is in particular important in light of different financing costs structures between low-carbon and fossil fuel energy supply technologies. 


\subsection{Aligning international plans with SDGs and African initiatives}

The German G20 Presidency has placed support for investment in Africa high on its agenda, calling for a "Compact with Africa" (Schäuble 2016). It intends to improve the investment climate as a catalyst for private investment. It is essential that these measures are closely aligned with the Sustainable Development Goals and the Paris Agreement to ensure that new infrastructure investments place African countries on sustainable development pathways, avoiding potentially costly lock-ins in unsustainable, high-carbon infrastructure. In practical terms, this means that investment partnerships to be negotiated in the G20 Finance Track should be linked to a broader development agenda, which explicitly accounts for the challenges of climate change and sustainable development.

Moreover, such investment partnerships should build on existing African initiatives, such as the African Union's Agenda 2063 and Africa Renewable Energy Initiative (AREI). A mapping of major energy initiatives in Africa conducted on behalf of the African Union, the Africa-EU Energy Partnership (AEEP) and Sustainable Energy for All (SE4ALL) provides an overview of the large number of existing initiatives in the energy sector (Quitzow et al. 2016a). The Africa Renewable Energy Initiative (AREI), for instance, aims to scale up renewable electricity in Africa by at least 300GW by 2030. Any new support schemes should take into account the existing landscape of initiatives and programs and should build on and expand existing initiatives. Existing information should be utilized to identify and close existing gaps in programming.

\subsection{Developing local leapfrogging strategies}

In the past, economic development strategies in Africa have been fashioned as catching-up strategies, based on technologies and markets in industrialized economies. In the energy sector, climate change and the related transformation of energy systems around the world are rendering this development option questionable (Fay et al., 2015). Moreover, the large decreases in costs for solar and wind energy technologies in the past decade have rendered an electricity system dominated by renewable energy increasingly feasible and affordable (Barasa et al., 2018; Schwerhoff and Sy, 2018; Ueckerdt et al., 2017).

There is currently no blueprint for an energy system that leapfrogs fossil energy carriers. Therefore, developing Africa's energy infrastructure will need to follow a forward-looking approach, which leverages emerging international technological trends to build local, lowcarbon development pathways. This relates not only to the choice of energy generation technologies, but also how they are distributed and integrated within the energy system. Advances in more decentralized approaches, i.e. renewable-based mini-grid and off-grid systems, have created increasingly cost-effective alternatives to grid extension as a strategy for rural electrification (Goel and Sharma, 2017).

The deployment of more decentralized solutions may also offer important opportunities for economic advancement and indigenous value creation, while avoiding the substantial risks of investing in emission intensive fossil-based energy technologies. One salient example it the 
growing market for solar off-grid appliances. "Pay-as-you-go" business models are proving particularly successful on the African continent, spurring investments in a growing number of African solar energy firms. From 2012 to 2017, approximately USD 773 million were raised in the market segment globally, well over 50 percent of which went to firms based in Africa (Dalberg Advisors; Lighting Global, 2018). These firms are offering accelerated and costeffective access to basic energy services to remote areas.

The benefits outlined above do not suggest that grid-connected energy services have lost their importance in national electrification strategies. Rather, they suggest that expansion of the electricity grid and promotion of off-grid electricity services should proceed hand in hand. The advantages of grid-based connectivity should be combined, where feasible and appropriate, with the benefits of decentralized energy technologies, which offer the potential to quickly and costeffectively improve electricity access in rural areas. Emerging planning tools for designing least-cost electrification strategies, which draw on the full spectrum of available technology options (i.e. grid extension, mini-grid and stand-alone systems) offer a promising avenue for policy makers to leverage available technology options for country-specific solutions to the electrification puzzle (Kemausuor et al., 2014; Mentis et al., 2017).

Given its climate benefits and significant implications for human health (see e.g., Martin et al. 2011; Anenberg et al. 2013) and forest protection (Bailis et al., 2015), it is also important to increase support for the adoption of clean cook stoves in Africa. Globally, the annual health costs of burning traditional biomass is estimated at USD 123 billion (ESMAP 2017). In 2012, a study found that fuelwood collection and charcoal production caused nearly 50 percent of forest degradation in Africa (Bruce et al., 2017), while accounting for 6 percent of global deforestation (Anenberg et al., 2013). Studies suggest that the introduction of clean cookstoves can reduce fuel use by 30 to 60 percent (Anenberg et al., 2013) and small particulate matter by 29 to 94 percent (Pope et al., 2017), depending on the type of stove and other socio-economic and environmental variables. Additional health and climate benefits may come from reductions in black carbon, a short-lived climate pollutant (Anenberg et al., 2013). Benefit-cost rations resulting from health-related impacts from cookstove interventions have been estimated to be as high as 10 to 1 in certain contexts (García-Frapolli et al., 2010).

Sub-Saharan Africa is the region that has made the least progress on clean cooking. Approximately 80 percent of households still rely on solid biomass for cooking. Despite increased efforts to increase the adoption of clean cookstoves, the absolute number of households using traditional methods of burning biomass continues to increase in sub-Saharan Africa. Between 2000 and 2015, the number of people relying on traditional biomass for cooking increased by USD 240 million (IEA 2017). Spending on clean cookstoves in so-called 20 high-impact countries has averaged USD 32 million per year, compared to an overall investment need of approximately USD 4 billion ${ }^{1}$. Ten of these high-impact countries are in sub-Saharan Africa. In comparison, total energy ODA commitments to those African countries stood at USD 1.4 billion in $2016^{2}$. This is also reflected in overall funding patterns for energy

\footnotetext{
1 See https://www.seforall.org/energy-access

2 See OECD.Stat, GeoBook: ODA by sector.
} 
access in Africa, which remains focused primarily on the electricity sector (Quitzow et al. 2016b). Given its health and climate benefits, clean cooking deserves increased support in the future.

\subsection{Leveling the playing field for low carbon energy technologies}

A transformation towards low-carbon energy supply needs to be supported by adequate policies that can incentivize changes. Currently, in most African countries incentive structures seem to rather favor fossil fuels than low-carbon alternatives. For example, inefficient fossil fuel subsidies that are in place in most African countries directly subsidize carbon emissions and are a major barrier for investments in low carbon infrastructure, such as renewable energy.

It is well understood, that policy changes to abolish fossil fuel subsidies need to be embedded in a broader sequencing of measures and actions. Rather than abolishing fossil fuel subsidies and eventually putting a price on carbon, fiscal incentives for alternative energy sources (such as feed-in-tariffs and tax breaks) might be easier to be implemented and would create groups that would directly benefit from (and which can hence be expected to lend political support to) green policies (Meckling et al. 2015).

In African countries, removing inefficient fossil fuel subsidy reforms, and - eventually introducing carbon pricing is often found to have progressive distributional effects, i.e., the poorest sections of the population are less affected than the rich (Dorband et al. 2017). Nevertheless, removing subsidies frequently has a negative impact on poor household incomes. To alleviate negative income effects a relatively small share of savings can be sufficient to finance adequate compensation schemes, as for example shown by Ghana (Lindebjerg et al. 2015). Additionally, revenues can be used to close existing infrastructure gaps and finance sustainable development goals (Jakob et al. 2015, Franks et al. 2018). Savings from fossil fuel subsidy reforms would be sufficient to cover a substantial share of investments required without depending on international transfers. This would enable national resources to be mobilized as demanded in the Addis Ababa Action Agenda.

\subsection{Derisking low carbon technologies}

The scaling-up of renewable energy in Africa is currently constrained by high financing costs in the individual countries. This includes but is not limited to the unfavorable sovereign credit rating of many African countries. It reflects a number of perceived or actual informational, technical, regulatory, financial and administrative barriers and their associated investment risk (Waissbein et al. 2013). Compared to fossil fuel based technologies, low-carbon technologies are more capital intensive and therefore affected by higher investment risks and financing costs (Schmidt 2014; Steckel and Jakob, 2018). In the absence of instruments to reduce capital costs of renewable energy, a first best climate policy such as carbon pricing would not be effective in triggering a low-carbon transformation in the energy system (Hirth and Steckel 2016). 
To address the existing investor risks and improve the competitiveness of renewable energy in Africa, G20 countries should support African policy makers to reduce policy risks and increasingly employ derisking instruments targeted at renewable energy investments. Those instruments, that can be applied both on the national as well as the international level, can address both underlying sources of risk (policy derisking) as well move private investors' risk to public entities (financial derisking).

Policy derisking refers to policy or programmatic interventions that seek to eliminate or substantially reduce existing risks of investments. In the renewable energy sector, typical risks might include a lack of clarity in the regulatory framework regarding access to the grid as well as uncertainty regarding permits and licenses for electricity generation, the use and acquisition of land, environmental impact assessment, etc. By introducing needed legislative or regulatory changes, policy makers can substantially reduce these risks. Institutional strengthening for policy implementation and targeted support for investors for overcoming investment hurdles can further mitigate sector-specific investment risks. Finally, dedicated strategies or targets for the promotion of renewables may reinforce such measures by signaling high-level political commitment. In this way, policy derisking can address the underlying barriers to investment and support the broader enabling environment for investment in renewable energy without the provision of direct financial support or the use of dedicated financing instruments.

Financial derisking instruments can be applied to transfer remaining risks from private investors to public actors, where appropriate. More specifically, such instruments should be employed for transferring project-related risks, which cannot be efficiently managed by private actors themselves. In many countries, the risk of default by a public off-taker (i.e. public utility) falls in this category. Similarly, residual political or regulatory risks, which cannot be fully mitigated by policy derisking especially at early stages of market development, may be addressed by financial derisking. Operational risks related to elements like resource availability, performance of the technology, construction, on the other hand, should, in principle, remain with developer who can and should take appropriate precautions. In very early stages of market development, a partial transfer of risks may be justified to kick-start the market and facilitate learning.

A range of so-called private sector instruments, such as guarantees, subordinated debt or equity, is already available for financial derisking and should be strengthened (Schwerhoff and Sy, 2017a; Steckel and Jakob, 2018; Torvanger et al. 2016). Public guarantees and other insurance-type financial products can be designed to transfer a clearly circumscribed risk to the public sector. Equity and subordinated debt represent vehicles to mitigate overall risk and may play a role in early stages of market development. More generally, the supplemental provision of project-based, non-recourse debt financing by public banks is justified in financing environments that lack private sector financial intermediaries with the expertise in assessing a specific project type. By crowding in lending from private banks, public lending can help facilitate the build-up of the required expertise over time, allowing the phase-out of public debt financing (Geddes et al., 2018; Mazzucato and Semieniuk, 2018).

To further bolster the use of private sector instruments in official development cooperation, the OECD's Development Assistance Committee has made important efforts to modernize its statistical system to capture risks taken by development agencies in the deployment of private 
sector instruments (OECD 2016). These changes to the reporting of ODA will provide additional incentives to donors for employing such instruments in the future. To further increase their overall use and effectiveness it will be essential to integrate them within comprehensive country-level derisking strategies. Those include both policy and financial derisking. In isolation, private sector instruments are likely to remain untapped as they can only target selected risks. It is essential that such financial instruments are embedded in a multi-pronged approach aimed at developing a stable investment climate for renewable energy.

\section{Conclusion}

While it is widely acknowledged that African countries will be highly vulnerable to climate change and related impacts, they are often neglected when it comes to discussions on climate change mitigation. Indeed, emissions (both in absolute terms and per capita) have proven to be extremely low in the past. This can partly be explained by the low levels of consumption resulting from high poverty rates and limited industrial development. However, looking at countries of East and South-East Asia, we should be reminded that economies can industrialize very quickly. If not accompanied by strong incentives for low-carbon development, this is likely to translate into a rapid growth in GHG emissions. While poverty headcount rates in Asia were comparable to sub-Sahara Africa in the 1990s, growth in the past decades has lifted hundreds of millions of people out of poverty. At the same time GHG emissions have increased dramatically as rising energy demand has often been fueled with emissions intensive fossil fuels.

Although the cost competitiveness of low-carbon energy technologies has increased, it cannot be taken for granted that African economic growth will be fueled by low-carbon energy. On the demand side, current policies frequently focus on providing energy access to cover basic needs. While important, this distracts from the fact that increasing prosperity will be accompanied by growing energy demand to power additional household appliances and productive uses. On the supply side, institutional path dependencies still favor investments in coal and other fossil fuel-based power generation technologies. To avoid the creation of new carbon lock-ins, additional measures and policies are required that can ensure that new investments in energy infrastructure are compatible with a long-term, low-carbon development pathway. These include measures to correct distorted incentive structures, which favor fossil fuels over cost competitive low-carbon options. These measures should be taken forward by African countries in their own self-interest and deserve concerted support from the international community. 


\section{References}

Ahrends, A., Burgess, N. D., Milledge, S. A. H., Bulling, M. T., Fisher, B., Smart, J. C. R., Clarke, G. P., Mhoro, B. E. and Lewis, S. L. (2010). Predictable waves of sequential forest degradation and biodiversity loss spreading from an African city. Proceedings of the National Academy of Sciences of the United States of America, 107(33): 14556-14561. https://doi.org/10.1073/pnas.0914471107

Allicott, H., Collard-Wexler, A. and O'Connell, S. D. (2016). How do electricity shortages affect industry? Evidence from India. American Economic Review, 106(3): 587-624. http://dx.doi.org/10.1257/aer.20140389

Alstone, P., Gershenson, D. and Kammen, D. M. (2015). Decentralized energy systems for clean electricity access. Nature Climate Change, 5(4): 305-314. https://www.nature.com/articles/nclimate2512

Anenberg, S. C., Balakrishnan, K., Jetter, J., Masera, O., Mehta, S., Moss, J. and Ramanathan, V. (2013). Cleaner cooking solutions to achieve health, climate, and economic cobenefits. Environmental Science and Technology, 47(9): 3944-3952. https://pubs.acs.org/doi/abs/10.1021/es304942e

Bailis, R., Drigo, R., Ghilardi, A. and Masera, O. (2015). The carbon footprint of traditional woodfuels. Nature Climate Change, 5: 266-272. https://www.nature.com/articles/nclimate2491

Barasa, M., Bogdanov, D., Oyewo, A. S. and Breyer, C. (2018). A cost optimal resolution for SubSaharan Africa powered by $100 \%$ renewables in 2030. Renewable and Sustainable Energy Reviews, 92: 440-457. https://doi.org/10.1016/j.rser.2018.04.110

Bensch, G., Grimm, M. and Peters, J. (2015). Why do households forego high returns from technology adoption? Evidence from improved cooking stoves in Burkina Faso. Journal of Economic Behavior and Organization, 116: 187-205. https://doi.org/10.1016/j.jebo.2015.04.023

Bensch, G. and Peters, J. (2013). Alleviating deforestation pressures? Impacts of improved stove dissemination on charcoal consumption in Urban Senegal. Land Economics, 89(4): 676-698. https://muse.jhu.edu/article/523040/pdf

Bren d’Amour, C., Reitsma, F., Baiocchi, G., Barthel, S., Güneralp, B., Erb, K. H., Haberl, H., Creutzig, F. and Seto, K. C. (2016). Future urban land expansion and implications for global croplands. Proceedings of the National Academy of Sciences, 114(34): 8939-8944. https://doi.org/10.1073/pnas.1606036114

Bruce, N., Aunan, K. and Rehfuess, E. (2017). Liquefied petroleum gas as a clean cooking fuel for developing countries: Implications for climate, forests, and affordability. KfW Development Bank. http://ccacoalition.org/en/resources/liquefied-petroleum-gas-clean-cooking-fuel-developingcountries-implications-climate

Calvin, K., Pachauri, S., Enrica De Cian, E. and Mouratiadou, I. (2016). The effect of African growth on future global energy, emissions, and regional development. Climatic Change, 136 (1): 109-125. https://doi.org/10.1007/s10584-013-0964-4

Creutzig, F., Agoston, P., Minx, J. C., Canadell, J. G., Andrew, R. M., Le Quéré, C., Peters, G. P., Sharifi, A., Yamagata, Y. and Dhakal, S. (2016). Urban infrastructure choices structure climate solutions. Nature Climate Change, 6(12): 1054-1056. https://www.nature.com/articles/nclimate3169

Csereklyei, Z. and Stern, D. I. (2015). Global energy use: Decoupling or convergence? Energy Economics, 51: 633-641. https://doi.org/10.1016/j.eneco.2015.08.029 
Dalberg Advisors and Lighting Global (2018). Off-grid solar market trends report 2018. International Finance Corporation. https://www.lightingglobal.org/2018-global-off-grid-solar-market-trendsreport/

Doig, A. and Adow, M. (2011). Low-carbon Africa: leapfrogging to a green future. Christian Aid. https://www.christianaid.org.uk/sites/default/files/2017-08/low-carbon-africa-leapfrogging-greenfuture-november-2011.pdf

Dorband, I., Jakob, M., Kalkuhl, M. and Steckel, J. (2017). Are poor households stronger impacted by carbon pricing? A global comparative analysis of distributional effects. Conference Paper: Annual Conference of the European Association of Environmental and Resource Economists (EAERE) 2017.

ESMAP (2017). Annual Report. World Bank Group. http://documents.worldbank.org/curated/en/171191523257054613/pdf/125049-AP-ESMAPAnnualReport-2017.pdf

Fay, M., Hallegatte, S., Vogt-Schilb, A., Rozenberg, J., Narloch, U. and Kerr, T. (2015). Decarbonizing development - three steps to a zero-carbon future. World Bank Group. http://www.worldbank.org/content/dam/Worldbank/document/Climate/dd/decarbonizingdevelopment-report.pdf

Fisher-Vanden, K., Mansur, E. T. and Wang, Q. J. (2015). Electricity shortages and firm productivity: evidence from China's industrial firms. Journal of Development Economics, 114: 172-188. https://doi.org/10.1016/j.jdeveco.2015.01.002

Franks, M., Lessmann, K., Jakob, M., Steckel, J. and Edenhofer, O. (2018). Mobilizing domestic resources for the Agenda 2030 via carbon pricing. Nature Sustainability, 1: 350-357. https://www.nature.com/articles/s41893-018-0083-3

García-Frapolli, E., Schilmann, A., Berrueta, V. M., Riojas-Rodríguez, H., Edwards, R. D., Johnson, M., Guevara-Sanginés, A., Armendariz, C. and Masera, O. (2010). Beyond fuelwood savings: Valuing the economic benefits of introducing improved biomass cookstoves in the Purépecha region of Mexico. Ecological Economics, 69(12): 2598-2605. https://doi.org/10.1016/j.ecolecon.2010.08.004

Geddes, A., Schmidt, T.S. and Steffen, B. (2018). The multiple roles of state investment banks in lowcarbon energy finance: An analysis of Australia, the UK and Germany. Energy Policy, 115: 158170. https://doi.org/10.1016/j.enpol.2018.01.009

Goel, S. and Sharma, R. (2017). Performance evaluation of stand alone, grid connected and hybrid renewable energy systems for rural application: A comparative review. Renewable and Sustainable Energy Reviews, 78: 1378-1389. https://doi.org/10.1016/j.rser.2017.05.200

Hassan, R. and Nhemachena, C. (2008). Determinants of African farmers' strategies for adapting to climate change: Multinomial choice analysis. African Journal of Agricultural and Resource Economics, 2(1): 83-104.

https://www.researchgate.net/publication/241239073_Determinants_of_climate_adaptation_strate gies_of_African_farmers_A_multinomial_choice_analysis

Hirth, L. and Steckel, J. C. (2016). The role of capital costs in decarbonizing the electricity sector. Environmental Research Letters, 11(11): 114010. http://iopscience.iop.org/article/10.1088/1748-9326/11/11/114010/pdf 
IEA (2016). World energy outlook 2016. Electricity Access database. http://www.worldenergyoutlook.org/resources/energydevelopment/energyaccessdatabase

IEA (2017). Energy access outlook: From poverty to prosperity. International Energy Agency. https://www.iea.org/publications/freepublications/publication/WEO2017SpecialReport_EnergyAc cessOutlook.pdf

Jakob, M., Chen, C., Fuss, S., Marxen, A. and Edenhofer, O. (2015). Development incentives for fossil fuel subsidy reform. Nature Climate Change, 5: 709-712. https://www.nature.com/articles/nclimate2679

Jakob, M., Haller, M. and Marschinski, R. (2012). Will history repeat itself? Economic convergence and convergence in energy use patterns. Energy Economics, 34 (1): 95-104. https://doi.org/10.1016/j.eneco.2011.07.008

Kemausuor, F., Adkins, E., Adu-Poku, I., Brew-Hammond, A. and Modi, V. (2014). Electrification planning using network planner tool: The case of Ghana. Energy for Sustainable Development, 19: 92-101. https://doi.org/10.1016/j.esd.2013.12.009

Lee, K., Miguel, E. and Wolfram, C. (2016). Appliance ownership and aspirations among electric grid and home solar households in rural Kenya. The American Economic Review, 106(5): 89-94. https://www.researchgate.net/publication/302973135_Appliance_Ownership_and_Aspirations_am ong_Electric_Grid_and_Home_Solar_Households_in_Rural_Kenya

Levesque, A., Pietzcker, R. C., Baumstark, L., De Stercke, S., Grübler, A., and Luderer, G. (2018). How much energy will buildings consume in 2100? A global perspective within a scenario framework. Energy, 148: 514-527. https://doi.org/10.1016/j.energy.2018.01.139

Lindebjerg, E. S., Peng, W., and Yeboah, S. (2015). Do policies for phasing out fossil fuel subsidies deliver what they promise? Social gains and repercussions in Iran, Indonesia and Ghana. UNRISD Working Paper No. 2015-1. http://unrisd.org/80256B3C005BCCF9/(httpAuxPages)/170D2DA8A96A5352C1257DC40050C9 75/\$file/Lindebjerg\%20et\%20al.pdf

Lucas, P. L., Nielsen, J., Calvin, K., McCollum, D.L., Marangoni, G., Strefler, J., van der Zwaan, B. and van Vuuren, D. (2015). Future energy system challenges for Africa: Insights from integrated assessment models. Energy Policy, 86: 705-717. https://doi.org/10.1016/j.enpol.2015.08.017

Mazzucato, M., and Semieniuk, G. (2018). Financing renewable energy: Who is financing what and why it matters. Technological Forecasting and Social Change, 127: 8-22. https://doi.org/10.1016/j.techfore.2017.05.021

Martin, W. J., Glass, R. I., Balbus, J. M. and Collins, F. S. (2011). A major environmental cause of death. Science, 334(6053): 180-181. http://science.sciencemag.org/content/334/6053/180

McCollum, D. L., Echeverri, L. G., Busch, S., Pachauri, S., Parkinson, S., Rogelj, J., ... and Riahi, K. (2018). Connecting the sustainable development goals by their energy inter-linkages. Environmental Research Letters, 13(3), 033006. http://iopscience.iop.org/article/10.1088/17489326/aaafe3

Meckling, J., Kelsey, N., Biber, E. and Zysman, J. (2015). Winning coalitions for climate policy. Science, 349(6253): 1170-1171. http://science.sciencemag.org/content/349/6253/1170 
Mentis, D., Howells, M., Rogner, H., Korkovelos, A., Arderne, C., Zepeda, E., Siyal, S., Taliotis, C., Bazilian, M., De Roo, A., Tanvez, Y., Oudalov, A. and Scholtz, E. (2017). Lighting the world: the first application of an open source, spatial electrification tool (OnSSET) on Sub-Saharan Africa. Environmental Research Letters, 12(8): 1-18. http://iopscience.iop.org/article/10.1088/17489326/aa7b29/meta

Mutanga, S. S., Simelane T. and Pophiwa N. (2013). Africa in a changing global environment. Perspectives of climate change adaptation and mitigation strategies in Africa. South Africa: Africa Institute of South Africa.

Niang, I., Ruppel, O.C., Abdrabo, M.A., Essel, A., Lennard, C., Padgham, J., Urquhart, P., Dube, P. and Leary, N. A. (2014). Africa. In Intergovernmental Panel on Climate Change. (2014). Climate change 2014: Impacts, adaptation, and vulnerability. Cambridge University Press. http://www.ipcc.ch/report/ar5/wg2/

Pachauri, S., van Ruijven, B. J., Nagai, Y., Riahi, K., van Vuuren, D. P., Brew-Hammond, A. and Nakicenovic, N. (2013). Pathways to achieve universal household access to modern energy by 2030. Environmental Research Letters, 8(2): 024015.

https://www.researchgate.net/publication/257068456_Pathways_to_achieve_universal_household_ access_to_modern_energy_by_2030

Peters, J. and Sievert, M. (2016). Impacts of rural electrification revisited-the African context. Journal of Development Effectiveness, 8(3): 327-345. https://doi.org/10.1080/19439342.2016.1178320

Pfeiffer, A., Millar, R., Hepburn, C., and Beinhocker, E. (2016). The '2 C capital stock'for electricity generation: Committed cumulative carbon emissions from the electricity generation sector and the transition to a green economy. Applied Energy, 179, 1395-1408.

https://doi.org/10.1016/j.apenergy.2016.02.093

Pope, D., Bruce, N., Dherani, M., Jagoe, K. and Rehfuss, E. (2017). Real-life effectiveness of "improved” stoves and clean fuels in reducing PM2,5 and CO: Systematic review and meta-analysis. Environment International, 101: 7-18. https://doi.org/10.1016/j.envint.2017.01.012

Quitzow, R., Röhrkasten, S., Berchner, M., Gotchev, B., Matschoss, P. and Peuckert, J. (2016a). Mapping of energy initiatives and progams in Africa. Africa-EU Energy Partnership. http://www.eueipdf.org/sites/default/files/field_publication_file/mapping_of_initiatives_final_report_may_2016.pdf

Quitzow, R., Röhrkasten, S., Jacobs, D., Bayer, B., Jamea, E. M., Waweru, Y. and Matschoss, P. (2016b). The future of Africa's energy supply. Potentials and development options for renewable energy. IASS Study. https://www.iass-potsdam.de/de/ergebnisse/publikationen/2016/future-africas-energysupply-potentials-and-development-options

Rao, N. D. and Pachauri, S. (2017). Energy access and living standards: some observations on recent trends. Environmental Research Letters, 12(2): 025011.

http://iopscience.iop.org/article/10.1088/1748-9326/aa5b0d

Schäuble, W. (2016). Speech by Dr. Wolfgang Schäuble, German Federal Minister of Finance, at the B20 conference on 1 December 2016 in Berlin. http://www.bundesfinanzministerium.de/Content/DE/Reden/2016/2016-12-01-b20.html

Shackleton, S., Ziervogel, G., Sallu, S., Gill, T., and Tschakert, P. (2015). Why is socially-just climate change adaptation in sub-Saharan Africa so challenging? A review of barriers identified from empirical cases. Wiley Interdisciplinary Reviews: Climate Change, 6(3), 321-344.

https://doi.org/10.1002/wcc.335 
Schmidt, T. S. (2014). Low-carbon investment risks and de-risking. Nature Climate Change, 4: 237-239. https://www.nature.com/articles/nclimate2112

Schwerhoff, G. and Sy, M. (2017). Financing renewable energy in Africa - Key challenge of the sustainable development goals. Renewable and Sustainable Energy Reviews, 75: 393-401. https://doi.org/10.1016/j.rser.2016.11.004

Schwerhoff, G. and Sy, M. (2018). Developing Africa’s energy mix. Climate Policy. In press. https://doi.org/10.1080/14693062.2018.1459293

Shearer, C., Ghio, N., Myllyvirta, L., Yu, A. and Nace, T. (2018). Boom and bust 2018. Tracking the global coal plant pipeline. CoalSwarm, Greenpeace and Sierra Club.

Steckel, J. C., Brecha, R. J., Jakob, M., Strefler, J. and Luderer, G. (2013). Development without energy? Assessing future scenarios of energy consumption in developing countries. Ecological Economics, 90: 53-67. https://doi.org/10.1016/j.ecolecon.2013.02.006

Steckel, J. C., Edenhofer, O. and Jakob, M. (2015). Drivers for the renaissance of coal. Proceedings of the National Academy of Sciences, 112(29): E3775-E3781. https://doi.org/10.1073/pnas.1422722112

Steckel, J.C., Hilaire, J., Jakob, M. and Edenhofer, O. (2018). Lions in the dragon's shoes? On carbonization patterns in Sub-Sahara Africa. MCC Working Paper. https://github.com/jhilaire/ssawosacarb

Steckel, J. C. and Jakob, M. (2018). The role of financing cost and de-risking strategies for clean energy investment. International Economics, 155: 19-28. https://doi.org/10.1016/j.inteco.2018.02.003

Torvanger, A., Pillay, K. and Clapp, C. (2016). Instruments to incentivize private climate finance for developing countries. CICERO Report.

http://www.cicero.uio.no/en/posts/selected-publications/instruments-to-incentivize-privateclimate-finance-for-developing-countries

Ueckerdt, F., Pietzcker, R., Scholz, Y., Stetter, D., Giannousakis, A. and Luderer, G. (2017). Decarbonizing global power supply under region-specific consideration of challenges and options of integrating variable renewables in the REMIND model. Energy Economics, 64: 665-684. https://doi.org/10.1016/j.eneco.2016.05.012

UNDP (2010). Energy for a sustainable future. Report and recommendations. http://www.un.org/millenniumgoals/pdf/AGECCsummaryreport[1].pdf

United Nations (2014). World urbanization prospects: The 2014 revision. https://esa.un.org/unpd/wup/publications/files/wup2014-highlights.pdf

Waissbein, O., Glemarec, Y., Bayraktar, H. and Schmidt, T.S. (2013). Derisking renewable energy investment. A framework to support policymakers in selecting public instruments to promote renewable energy investment in developing countries. UNDP.

http://www.undp.org/content/dam/undp/library/Environment\%20and\%20Energy/Climate\%20Strat egies/UNDP\%20Derisking\%20Renewable\%20Energy\%20Investment\%20-

\%20Full\%20Report\%20(April\%202013).pdf 


\section{Economics}

Please note:

You are most sincerely encouraged to participate in the open assessment of this article. You can do so by either recommending the article or by posting your comments.

\section{Please go to:}

http://dx.doi.org/10.5018/economics-ejournal.ja.2018-61

The Editor 